\title{
Where to produce rapeseed biodiesel and why? Mapping European rapeseed energy efficiency
}

\author{
Iris van Duren ${ }^{a,}{ }^{*}$, Alexey Voinov ${ }^{\mathrm{a}, 1}$, Oludunsin Arodudu ${ }^{\mathrm{a}, \mathrm{b}}$, Melese Tesfaye Firrisa ${ }^{\mathrm{a}}$ \\ a University of Twente, Faculty of Geo-Information Science and Earth Observation (ITC), P.O. Box 217, Hengelosestraat 99, 7514 AE Enschede, The \\ Netherlands \\ ${ }^{\mathrm{b}}$ Leibniz-Centre for Agricultural Landscape Research (ZALF), Eberswalder Straße 84, 15374 Müncheberg, Germany
}

\section{A R T I C L E I N F O}

\section{Article history:}

Received 18 July 2013

Accepted 14 July 2014

Available online 20 August 2014

\section{Keywords:}

Biomass feedstock

EROEI

GIS

Energy policy

Sustainable yield

Zoning

\begin{abstract}
A B S T R A C T
Rapeseed is widely used to produce biodiesel, especially in Europe. In several studies, it has been shown that there is a good potential for growing this crop across the continent. However there is still little awareness that the energy efficiency of biofuel production from rapeseed is very low. Energy efficiency can be expressed in terms of Energy Return for Energy Invested (EROEI). We mapped EROEI values for all EU countries plus Switzerland based on expected yields derived from rapeseed suitability maps. We find that EU countries produce rapeseed biofuel with EROEI values of 2.2 and lower. We suggest that plans for biofuel cropping have to be supplemented by maps of EROEI. It is not only relevant to show where rapeseed can be grown, but we should also look at where its use for bioenergy can be efficient. In the area theoretically suitable for growing rainfed rapeseed (excluding unsuitable areas and water), $37.6 \%$ of the area can produce rape methyl ester (RME) biofuel only with an energy loss. We conclude that the energy efficiency of rapeseed biodiesel is low and spatially heterogeneous, and unless there are major technological improvements in the production process, replacing fossil fuels by biofuels from rapeseed is hardly a feasible option.
\end{abstract}

๑) 2014 Elsevier Ltd. All rights reserved.

\section{Introduction}

Energy is the driving force for economic development [1]. So far, fossil fuels (e.g. petroleum, coal etc.) are the main source of energy. Most of the advances in livelihoods and life quality that we enjoy today can be traced back to the abundant and cheap supply of fossil fuels that humanity has been enjoying over the past century. However, the present continuous reliance on fossil fuels becomes risky for several reasons. First and foremost, this resource is nonrenewable and, currently its consumption is by far faster than its rate of formation, and even discovery. As reserves shrink, extracting fossil fuels becomes more difficult and expensive, and eventually will be cost inefficient. There are also environmental and human costs involved in extraction and production of fossil fuels. Besides, fossil fuel consumption produces greenhouse gases (GHG), which

\footnotetext{
* Corresponding author. Tel.: +31 (0)53 4874313; fax: +31 (0)53 4874388.

E-mail addresses: i.c.vanduren@utwente.nl, vanduren@itc.nl (I. van Duren), a.a. voinov@utwente.nl (A. Voinov), Oludunsin.Arodudu@zalf.de (O. Arodudu), firrisa21744@alumni.itc.nl (M.T. Firrisa).

${ }^{1}$ Tel.: +31 (0)53 4874507; fax: +31 (0)53 4874388 .
}

have been clearly shown to be a major driver of climate change globally $[2,3]$. According to some estimates, $80 \%$ of the remaining fossil fuel should stay in the ground if we are to avoid extreme consequences of climate change [4]. Moreover, much of the remaining fossil fuels are contained in and have to be imported from politically unstable countries, making supply unreliable [5]. These problems draw our attention to the search for alternative energy sources [6], out of which biofuel energy looks like a promising one. Compared to fossil fuels, alternative energy sources in general and biofuels in particular bear much promise in terms of lower environmental impacts, improved energy security and less socio-economic externalities [7-14].

Biofuels are derived from plants, and can be used directly for heat, electricity production or converted to liquid fuel [15]. This latter use makes them especially attractive as a substitute for energy in transportation, which currently predominantly relies on liquid fossil fuels. Currently biomass fuels are the only alternative to liquid fossil fuels [18,19], and, they can be used in unmodified conventional diesel-engines as in the case of Fischer-Tropsch (FT) biodiesel [20]. Worldwide corn, wheat, barley, sugarcane, rapeseed, oil palm, soybean, sugar beet, potato, sunflower [15-17], etc. are used for biofuel production. The European Union was the world 
leader in biodiesel and third in biofuel production in 2005 [7]. Out of the total of 10.2 billion liters of biodiesel produced worldwide in $2007,60 \%$ was produced in the EU, where rapeseed is the major oil crop $[7,16,25]$ accounting for more than half of the production [26]. In 2008, $79 \%$ of all biodiesel feedstock crops in Europe was rapeseed [16] and it was cultivated in most European countries [27,28].

The increasing demand for energy in general and the growing role of biofuels in meeting this demand makes it especially important to understand all the implications and consequences of biofuel production [24]. A major controversy is that biofuel production relies on the same crops that can be used for food production [7,21]. For example, biodiesel is mainly produced from vegetable oils such as rapeseed oil, sunflower seed oil, soybean oil, all of which can be also used in the food chain [12,21]. Growing demand for biofuels may increase food prices and has direct impact on land use and biodiversity [6,11,13,14,22-24]. Another major concern is the overall efficiency of biofuel production [29]. Agricultural systems vary in energy inputs and outputs. Different agroecological areas have different agronomic practices $[10,30]$ and are influenced by different biophysical factors [31]. This in turn influences the efficiency of biomass production. Obviously, studying the energy efficiency of a biofuel production system under different agro-ecological and agricultural practices plays a vital role in selecting and optimizing the technology in each type of environment and understanding the overall viability of the biofuel future.

Production of energy from bio-resources is a function of land, labor, water, raw materials, etc. [35], which adds a strong spatial component to the process. Production has to occur on vast areas of land in various agro-ecological conditions [39]. There were previous attempts to present the spatial variability of rapeseed production in Europe [40]. Land suitability and potential yield of rapeseed was mapped on a $1 \mathrm{~km}$ grid base across Europe. In our study we expand these results by studying the efficiency of biofuel production and accounting for the energy input and output factors.

A widely used efficiency indicator of the energy production process is the energy return on energy investment (EROEI), which is calculated from the following equation [33-37]:

$\mathrm{EROEI}=E_{\mathrm{out}} / E_{\mathrm{in}}$

where $E_{\text {out }}$ is the amount of energy produced, and $E_{\text {in }}$ - the amount of energy used in production. Clearly, an EROEI value of close to one or less makes production thermodynamically meaningless as much or even more energy is needed for energy production than what is produced [38]. According to some estimates, a minimum EROEI of 3 should be achieved to make sure that the energy production is economically, environmentally and socially acceptable [34]. This is to compensate for numerous externalities involved in the process (land and water quality degradation, pollution, etc.), which are hard to express in energy values and fully account for in the EROEI calculations. There have been previously some concerns raised about the overall energy efficiency of biofuel production. For example, energy efficiency for corn ethanol for the entire US on county level (for yield) and state level (for fertilizers and irrigation) showed EROEI values ranging spatially from 0.87 to 1.27 [29]. In this paper we produce a spatial analysis of rapeseed energy production efficiency for Europe and show where it makes most sense to produce biodiesel from rapeseed and where it should be discouraged.

We largely base our results on a previous study of rapeseed EROEI [30]. In that study a computational input/output model was developed to determine energy production efficiency of the rapeseed biofuel production process comparing different farming systems. Interviews with Dutch farmers, conducted during that study also indicated that farmers do not care much for which purposes the crop is used. They will sell to a buyer from the food industry as well as to an energy producer or to any other buyer as long as they receive a good price for the product. The energy efficiency in the crop production stage is, therefore, not really much different for the various uses of the rapeseed oil. Therefore we assume that all areas are evaluated for their potential in producing rapeseed biofuel and to make clear where in Europe this may be energetically beneficial and where not.

Extending previous research on spatial variability of rapeseed production in Europe [40], we map the EROEI of this process to find that using this crop for bioenergy purposes also raises some concerns in terms of efficiency. We focus on biofuel production from winter rapeseed, which is the most abundant crop type due to a higher achievable crop yield compared to summer rapeseed. It is also more popular because having a crop with a high level of ground coverage on the land during winter reduces soil erosion and is considered more ecologically friendly [41].

\section{Materials and methods}

Mapping EROEI was carried out for the twenty-seven current member countries of the European Union and Switzerland. The approach was to combine a Life Cycle Inventory (LCI) based EROEI model and yield maps (derived from a suitability map) with longterm yield assessment. The underlying assumption is that the yield of rapeseed very much determines the energy production efficiency and varies with different agro-ecological conditions for the same production inputs. For our analysis, we use three major sources of information.

The Global Agro-Ecological Zones (GAEZ) project, a collaborative effort between the Food and Agricultural Organization of the United Nations (FAO) and the International Institute for Applied System Analysis (IIASA), has produced suitability maps for rain-fed oil crops for the whole of Europe. The GAEZ suitability map defines the percentage of the maximum attainable yield that can be expected for a given location based on the agro-ecological and climatic conditions there [40]. We combined the GAEZ suitability map with a computational input/output model that was based on Life Cycle Inventory and farmer interviews conducted in Poland and the Netherlands [30]. A previous paper by Firrisa et al. [30] describes in detail all inputs, outputs, assumptions and conversion factors used in this analysis. An important input parameter in the calculation model is the yield. By interpreting the suitability classes in terms of expected yields and linking them to the computational model described in Ref. [30] here we have produced energy efficiency maps for Europe. Next, we used FAO data on rapeseed production for the last 50 years [42] to validate and compare the results that came from the suitability analysis, and to refine the energy estimates based on country-specific conditions. We then used the map of rapeseed production in the Netherlands obtained from the Dutch Ministry of Agriculture [43] to zoom into country-specific conditions in the Netherlands.

The Global Agro-Ecological Zones (GAEZ) model utilized a land resources inventory to assess feasible agricultural land use options and to quantify expected yield resulting from cropping activities. The approach took into account specific agro-ecological contexts for well-specified management conditions and levels of inputs. The characterization of land resources included components of climate, soils and landform, which are basic for the supply of water, energy, nutrients and physical support to plants. The GAEZ suitability maps are based on a half-degree latitude/longitude world climate data set, 5-min soils data derived from the digital version of the FAO Soil Map of the World, the 30 arc-seconds Global Land Cover Characteristics Database, and a 30 arc-seconds digital elevation data set [44]. The resulting suitability map has eight suitability classes and a ninth class "water". 
After downloading the global suitability map for rainfed rapeseed [44], further processing and analysis followed in a Geographical Information System. The map was clipped to the extent of Europe using imported shape files of countries [45] and polygonized for further processing. All maps were reprojected to the continental European projection system (ETRS 1989 using the Lambert Azimuthal Equal Area projection available in ArcGIS). Intersecting the suitability map with individual country areas enabled extracting the area per suitability class in each country. We validated the numbers at the start of the analysis by comparing for each country the total land area taken from the country maps with the country sizes given on the EU website. On the average the difference was $0.28 \%$ with the largest difference of around $1 \%$ for France and Bulgaria. It was expected that the course resolution of the GAEZ suitability map would introduce inaccuracies in land areas. Therefore we performed another evaluation of the land area after intersecting the country maps with the suitability map. Large landlocked countries hardly suffered from land loss due to intersecting the maps. Malta, however, could not be reliably mapped with the GAEZ scheme as $24 \%$ of the area of this small island in the Mediterranean was lost due to the intersection. Mild impact of land loss due to intersection was observed for countries with relatively long coastlines (Denmark 8.5\%, Cyprus 6.8, Ireland 5.0, UK 4.8 and the Netherlands 3.5\%). For our purpose the quality of the map resulting from the intersection was however sufficient for further analysis.

The suitability map was converted into a yield map by taking the maximum attainable yield (MAY) and multiplying it by the suitability index. Instead of using ranges (like in GAEZ) we took the average of the maximum and minimum values. In the GAEZ model, MAY for rapeseed was given for different levels of inputs in terms of fertilizers, chemicals and cultivation practices, such as periods under fallow. The idea was to look at sustainable MAYs, which are those which can be sustained over long periods of time, so that agricultural use does not destroy soil fertility and does not result in land degradation. For temperate environments under rainfed conditions, the GAEZ study included three levels of MAY (Table 1) [44]. Basically this means that higher MAYs require more input of fertilizers and other agricultural efforts to make sure that the yields are not destroying soil fertility. Note that the MAYs here are significantly lower than the maximal yield of $5.2 \mathrm{t} /$ ha reported by FAO for Luxembourg in 1980 [42]. While being higher, that yield probably cannot be considered as sustainable. So we did not use this MAY further in our analyses.

The Global Agro-Ecological Zones (GAEZ) project converted the rapeseed yield map to present the biofuel energy potential. However, only the output energy was calculated in their study with no account of the 'cost' of production of this energy. In our study, we moved the analysis further by also considering energy inputs that are required to produce rapeseed and then the products into to produce energy. We applied the computational model of Firrisa et al. [30] to calculate the EROEI values for the different suitability classes under high, medium and low input using the MAY values of Table 1 . The following energy flows were taken into account in the

Table 1

Average of year 1960-1996, simulated maximum attainable (sustainable) yield (MAY) ranges $(\mathrm{kg} / \mathrm{ha}$ ) across Europe for rapeseed for high, intermediate, and low level inputs in temperate environments under rain-fed conditions.

\begin{tabular}{llll}
\hline & $\begin{array}{l}\text { High input } \\
\text { yields } \\
(\mathrm{kg} / \mathrm{ha})\end{array}$ & $\begin{array}{l}\text { Intermediate } \\
\text { input yields } \\
(\mathrm{kg} / \mathrm{ha})\end{array}$ & $\begin{array}{l}\text { Low input } \\
\text { yields } \\
(\mathrm{kg} / \mathrm{ha})\end{array}$ \\
\hline Ranges from GAEZ [44] & $3900-4400$ & $\begin{array}{l}2300-3000 \\
2650\end{array}$ & $\begin{array}{l}1000-1300 \\
1000\end{array}$ \\
\hline MAY values used in our analysis & 4400 & 2600 \\
\hline
\end{tabular}

model (all energy inputs and outputs at farm level were expressed as energy (in mega joule per hectare)).

\subsection{Inputs}

- Cultivation Energy: The amount of energy in the form of diesel fuel used for driving the tractor and operating the machinery to cultivate the land multiplied by the energy content of diesel.

- Fertilizer Production Energy: The energy required for the production of the three major mineral fertilizers: nitrogen, phosphorus and potassium multiplied by the quantities of fertilizers. When raw manure was used as a substitute for mineral fertilizers, we assumed its energy production costs to be zero as manure can be seen as waste or side product.

- Crop Protection Energy: The energy required for production of insecticides, herbicides and fungicides multiplied by an energy conversion factor and quantities used by farmers.

- Transportation Energy: The energy required for round trips between the farm house and field and from the field to the processing site multiplied by the energy content of diesel.

- Feedstock Production Energy: The total energy required to produce the per-hectare feedstock and deliver it to the biofuel processing plant.

- Conversion energy: The energy for extraction, refining and RME production is dependent on the rapeseed yield and amount of biodiesel produced from it.

\subsection{Outputs}

- Energy output in the form of biodiesel or RME: The proportion of biodiesel with the same energy content as $1.00 \mathrm{~kg}$ of fossil diesel multiplied by the energy conversion factor of fossil fuel diesel.

- The by- and waste products considered in the calculation were rapeseed straw, meal (cake), and glycerin.

- Leaving straw, roots and empty pods after harvesting the seeds on the land causes an assumed reduction in the use of fertilizers. There is an average value used in many Life Cycle Assessments and it assumes that the amount of straw that becomes available as fertilizer is not dependent upon yield.

- The real energy content of rapeseed meal is unknown and, therefore, calculations are based on substituting rapeseed meal with another animal feedstock with a known energy value and an equal price.

- The energy production in the form of glycerin is seen as a percentage of the total energy requirements to produce biodiesel.

The problem with yield-based EROEI calculations is that the same yield can be obtained from highly suitable lands under lower maximum attainable yield (MAY) values as from less suitable lands but with higher MAY values. In the latter case, more fertilizers and more pesticides need to be used, which translates into higher energy investments. The actual conversion of rapeseed to biodiesel involves a more or less standard procedure and can be expected to have the same energy requirements over the whole of Europe. But we also need to account for the variability of conditions under which rapeseed is grown. Since we have insufficient information about what actual input farmers provide we started with simulating and comparing three EROEI maps that illustrate rapeseed biofuel production under standardized high, medium and low input levels over Europe.

Then, we took the FAO reports on rapeseed productivity in European countries and compared three scenarios under which: 
Table 2

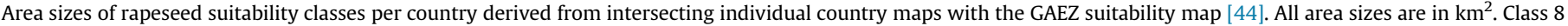
(unsuitable) and class 9 (water) are not included.

\begin{tabular}{|c|c|c|c|c|c|c|c|c|}
\hline Country & Class 1 & Class 2 & Class 3 & Class 4 & Class 5 & Class 6 & Class 7 & Total \\
\hline Austria & 2274 & 11,172 & 7088 & 5299 & 4454 & 9909 & 9908 & 83,920 \\
\hline Belgium & & 2811 & 5450 & 6658 & 5665 & 4460 & 5409 & 30,454 \\
\hline Bulgaria & 250 & 2905 & 21,643 & 32,454 & 23,453 & 24,878 & 4596 & 110,704 \\
\hline Cyprus & & & & & 135 & 2249 & 5294 & 8618 \\
\hline Czech Republic & 4574 & 10,933 & 22,438 & 22,452 & 9854 & 7207 & 1363 & 78,869 \\
\hline Denmark & 551 & 6932 & 10,705 & 3585 & 5998 & 7130 & 3898 & 39,644 \\
\hline Estonia & 408 & 3942 & 10,383 & 1743 & 5675 & 16,842 & 3212 & 44,033 \\
\hline Finland & & & 2574 & 6339 & 13,578 & 19,086 & 1412 & 332,137 \\
\hline France & 4302 & 23,494 & 64,317 & 137,106 & 95,639 & 98,703 & 33,777 & 544,380 \\
\hline Germany & 38,448 & 47,758 & 66,562 & 69,797 & 41,252 & 61,626 & 15,163 & 355,395 \\
\hline Greece & & 265 & 760 & 10,735 & 16,123 & 52,071 & 23,020 & 122,833 \\
\hline Hungary & 562 & 9602 & 25,285 & 21,333 & 11,761 & 12,479 & 6754 & 93,011 \\
\hline Ireland & & & 94 & 2923 & 1888 & 23,414 & 11,430 & 66,471 \\
\hline Italy & 2404 & 26,836 & 12,638 & 16,045 & 36,848 & 112,292 & 46,924 & 295,818 \\
\hline Latvia & 11,045 & 21,063 & 22,203 & 7215 & 915 & 712 & 521 & 63,769 \\
\hline Lithuania & 15,402 & 25,429 & 14,026 & 7898 & 1908 & & & 64,747 \\
\hline Luxembourg & & 2 & 58 & 156 & 873 & 1452 & 56 & 2596 \\
\hline Malta & & & & 119 & 118 & & & 237 \\
\hline Netherlands & 33,951 & 34,802 & 54,636 & 45,822 & 23,216 & 98,175 & 13,117 & 311,496 \\
\hline Poland & & & 3067 & 4294 & 16,526 & 21,358 & 7884 & 87,662 \\
\hline Portugal & & & 3067 & 4294 & 16,526 & 21,358 & 7884 & 87,662 \\
\hline Romania & 1180 & 13,896 & 54,791 & 66,912 & 33,918 & 46,430 & 5694 & 237,673 \\
\hline Slovakia & 1341 & 4629 & 7741 & 7257 & 5313 & 17,663 & 2722 & 49,014 \\
\hline Slovenia & 709 & 2119 & 1731 & 2465 & 3032 & 7016 & 1241 & 20,213 \\
\hline Spain & & & 825 & 4652 & 24,023 & 116,814 & 57,957 & 499,100 \\
\hline Sweden & & 9052 & 7849 & 15,583 & 29,091 & 47,274 & 15,311 & 443,073 \\
\hline Switzerland & 173 & 4793 & 2944 & 2639 & 2484 & 3426 & 3610 & 41,281 \\
\hline United Kingdom & & 7083 & 13,903 & 43,106 & 45,920 & 46,736 & 25,600 & 232,926 \\
\hline EU + Switzerland & 117,572 & 269,516 & 436,776 & 548,880 & 476,188 & 880,759 & 313,757 & $4,347,734$ \\
\hline
\end{tabular}

1. Rapeseed production is uniformly distributed across all suitability classes, or

2. Rapeseed production only takes place in the 4 highest suitability classes, or

3. Only the 3 highest suitability classes are used for rapeseed production.

The comparison of the productivity calculated across Europe (based on the reclassified GAEZ data and the different MAYs from Table 1) with actual productivities reported by FAO was done as follows:

- For a given MAY value, based on the suitability map, the countrywide average yield was calculated by taking all the cells in a particular country.

- Yield was calculated in each of the cells according to their suitability, was summed up and divided them by the area of the country.

- Results were compared to the results that FAO reports for rapeseed productivity in different European countries [42].

A similar procedure was followed when calculating EROEI values for the scenarios where rapeseed was grown in the four or three highest suitability classes. But then the yields of the four or three most suitable classes were summed up and divided by the total area of the four or three highest suitability classes.

The last step was zooming into the rapeseed production patterns in the Netherlands, where we actually know where rapeseed is grown. The rapeseed field areas of 2009 [43] were intersected with the polygonized GAEZ suitability map $[44,45]$. Areas per class were extracted and compared with the FAO data. The FAO reported 2600 ha harvested area of rapeseed for the Netherlands in 2009. Since we came to a somewhat lower number we looked in more detail at the datasets. The field data from the Ministry of Agriculture included winter and summer rapeseed (2452 ha vs. 168 ha respectively). The computational model of Firrisa et al. [30] used for previous analysis was developed for winter rapeseed. After including this correction the two datasets matched closely.

\section{Results}

Main input for the analysis was the amount of land available in the different suitability classes per country. This is presented in Table 2. The total surface of our study area (EU + Switzerland) was 4379 thousand $\mathrm{km}^{2}$ of which 3043 thousand $\mathrm{km}^{2}$ or $69.5 \%$ fell in the suitability classes 1 to 7 . Class 8 (unsuitable) and 9 (water) were ignored in our research.

To map spatial distributions of energy efficiency under three different MAYs the suitability classes were translated into expected yield. These yields are provided in Table 3.

The yield values from Table 3 were translated into energy input, energy output and EROEI values based on the computational model of Firrisa et al. [30]. These are shown in Table 4. Also the percentage of land available per suitability class in the study area is indicated. From Table 4 it can be observed that, not

Table 3

Expected rapeseed yields in the GAEZ suitability classes under three different input scenarios. High input production is assumed to result in a maximum attainable yield of $4400 \mathrm{~kg} / \mathrm{ha}$, intermediate input allows a yield of $2650 \mathrm{~kg} / \mathrm{ha}$ and low input production yields $1000 \mathrm{~kg} / \mathrm{ha}$ maximum.

\begin{tabular}{llllll}
\hline $\begin{array}{l}\text { Suitability } \\
\text { class }\end{array}$ & Suitability index & $\begin{array}{l}\text { Average } \\
\text { index }\end{array}$ & $\begin{array}{l}\text { Yield for } \\
\text { MAY 4400 }\end{array}$ & $\begin{array}{l}\text { Yield for } \\
\text { MAY 2650 }\end{array}$ & $\begin{array}{l}\text { Yield for } \\
\text { MAY 1000 }\end{array}$ \\
\hline Class 1 & $85-100 \%$ of MAY & 0.925 & 4070 & 2451 & 925 \\
Class 2 & $70-85 \%$ of MAY & 0.775 & 3410 & 2054 & 775 \\
Class 3 & $55-70 \%$ of MAY & 0.625 & 2750 & 1656 & 625 \\
Class 4 & $40-55 \%$ of MAY & 0.475 & 2090 & 1259 & 475 \\
Class 5 & $25-40 \%$ of MAY & 0.325 & 1430 & 861 & 325 \\
Class 6 & $5-25 \%$ of MAY & 0.15 & 660 & 398 & 150 \\
Class 7 & $0-5 \%$ of MAY & 0.025 & 110 & 66 & 25 \\
\hline
\end{tabular}


Table 4

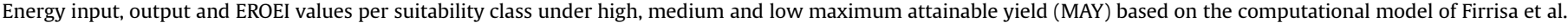
[30].

\begin{tabular}{|c|c|c|c|c|c|c|c|c|}
\hline & & Class 1 & Class 2 & Class 3 & Class 4 & Class 5 & Class 6 & Class 7 \\
\hline \multirow[t]{3}{*}{ MAY 4.4} & Input (MJ/ha) & 29,000 & 26,168 & 23,337 & 20,505 & 17,674 & 14,371 & 6242 \\
\hline & Output (MJ/ha) & 64,461 & 54,595 & 44,729 & 34,864 & 24,998 & 13,488 & 3456 \\
\hline & EROEI & 2.2 & 2.1 & 1.9 & 1.7 & 1.4 & 0.9 & 0.3 \\
\hline \multirow[t]{3}{*}{ MAY 2.65} & Input (MJ/ha) & 22,055 & 20,350 & 18,645 & 16,939 & 15,234 & 13,245 & 6054 \\
\hline & Output (MJ/ha) & 40,264 & 34,322 & 28,380 & 22,438 & 16,496 & 9564 & 2802 \\
\hline & EROEI & 1.8 & 1.7 & 1.5 & 1.3 & 1.1 & 0.7 & 0.2 \\
\hline \multirow[t]{3}{*}{ MAY 1.0} & Input (MJ/ha) & 15,508 & 14,864 & 14,221 & 13,577 & 12,934 & 12,183 & 5877 \\
\hline & Output (MJ/ha) & 17,449 & 15,207 & 12,965 & 10,723 & 8481 & 5865 & 2185 \\
\hline & EROEI & 1.1 & 1.0 & 0.9 & 0.8 & 0.7 & 0.5 & 0.2 \\
\hline
\end{tabular}

surprisingly, lower suitability classes with low yields result in low EROEI values. All EROEI values close to or lower than 1 are areas where production of biofuel costs more energy than what is obtained. From the table we can also derive that the higher MAYs involve higher energy inputs resulting in higher energy outputs compared to lower MAYs. These investments result in relatively higher EROEI values but these increases are modest compared to the increase in energy input.

The spatial distributions of EROEI values are shown in Fig. 1. In the GAEZ suitability maps, we can see that rapeseed can be grown over large areas. However, our EROEI maps show that energetically it makes sense to grow it only in particular areas with at least medium input in rapeseed production. It will be hardly useful to grow rapeseed for fuel in areas with an EROEI lower than 1.5, where we are too close to losing energy in the production process. All GAEZ suitability classes 5-7 are actually located in such areas. This amounts to $54.9 \%$ of the total area theoretically suitable for rapeseed production. The majority of the areas with relatively high EROEI values are located in Germany, Poland, Lithuania, Latvia, France and Italy. However even those areas have a maximum EROEI of 2.2 , which is not very high.

The next step was to validate the suitability based yields by comparing them with the FAO reports on rapeseed yields. In Fig. 2 we present country-based FAO data with the productivities calculated under the assumption that all suitability classes are used for rapeseed production (scenario 1 ).

In this figure we have separated the FAO data for 1960-96 and the 1996-2009 data. Interestingly during the last decade rapeseed productivity has increased by almost $30 \%$ compared to the previous three decades as can be seen in Fig. 3. The possible factors responsible for this increase are not properly documented nor explicitly clear in such time series. But it is likely related to more efficient agricultural practices, including improved crop varieties and/or shifting rapeseed production to more suitable and fertile areas and/or using more energy for fertilizers and land cultivation. Again, we do not know to what extent this increase in productivity is associated with higher energy inputs. Are we "buying" higher yields by investing more fossil energy in the production? In that case this is hardly helpful if rapeseed is grown as an energy crop. The GAEZ estimates for MAY were for 1960-1996. Therefore, we ranked all countries according the FAO reported average yields for these years.

Also shown in Fig. 2 are the productivities calculated for all countries based on the various MAY estimates from Table 1, and assuming that average countrywide suitability is used. Note that while the European average is somewhere in the center, most of the developed Western European countries are to the left, while most of the Eastern European countries are to the right. The actual productivity in Western Europe is consistently higher than MAY estimates, whereas the actual productivity in Eastern Europe is usually within the MAY estimates.
Fig. 4 presents EROEI values for scenario 2 and 3, assuming that rapeseed production is limited to respectively the top 4 and top 3 suitability classes. Now we can see that the FAO data are quite well matched for the Western European countries, while in Eastern Europe the FAO results are significantly lower than the GAEZ average estimate.

Apparently, the GAEZ numbers and the FAO records are in better agreement if we assume that 1) in Western Europe production is skewed towards the most suitable classes; 2) in Eastern Europe production is either quite evenly distributed across various suitability classes (Fig. 4) or if it is also skewed towards the most suitable classes, than it is conducted at lower MAY $=2650 \mathrm{~kg} / \mathrm{ha}$. It is only under these assumptions that we can bring the two datasets closer together. On the one hand it makes a lot of sense to assume that indeed rapeseed is currently grown in areas that are more suitable. On the other hand, the difference in productivities that we find in the FAO results (Fig. 3) seems to match the observations made by Firrisa et al. [30] who have found that in the Netherlands rapeseed production is somewhat more efficient than in Poland. Assuming production at high MAY level in countries to the left of the European average productivity in Fig. 4 and medium MAY level in countries to the right of "Europe", we can produce the map of Fig. 5. From this map we see that under current agricultural practices, there is only about $10 \%$ of suitable land where rapeseed can be produced with an EROEI over 2 and on almost 53\% of the land we are close to or effectively losing energy when producing rapeseed for biodiesel.

Looking in more detail at the Netherlands we analyzed the distribution of the actual rapeseed fields of 2009 over the GAEZ rapeseed suitability classes. This is shown in Fig. 6. Note that the coarse resolution of the GAEZ classes causes inaccuracies when zooming in to local scale and field based analysis.

We observe that there is a high density of rapeseed fields in relatively suitable areas in the Northeast of the country. The visual interpretation is confirmed by the analysis of actual field distribution compared to what is expected based on uniform distribution overall suitability classes (Table 5). We found that more rapeseed is produced in the higher suitability classes and less in suitability classes 6 and 7. So apparently our assumption about production skewed towards the more suitable classes holds.

Translating this into expected yields, we calculated a total yield of around 6,000, 3600 and $1400 \mathrm{~kg}$, respectively, under the different MAY assumptions. The calculated yield for the highest MAY is, however, way lower than the reported 10,541 kg reported in the FAO data for 2009. Taking the long-term (1996-2009) average productivity of $3700 \mathrm{~kg} / \mathrm{ha}$ for Netherlands, we get a much closer value: $8451 \mathrm{~kg}$. We checked the Dutch rapeseed productivity figures and observed that 2009 was an exceptional year with much higher yields than the previous years (Table 6). The average yield reported by FAO is $4620 \mathrm{~kg} / \mathrm{ha}$, which is higher than the MAY of $4400 \mathrm{~kg} / \mathrm{ha}$. 

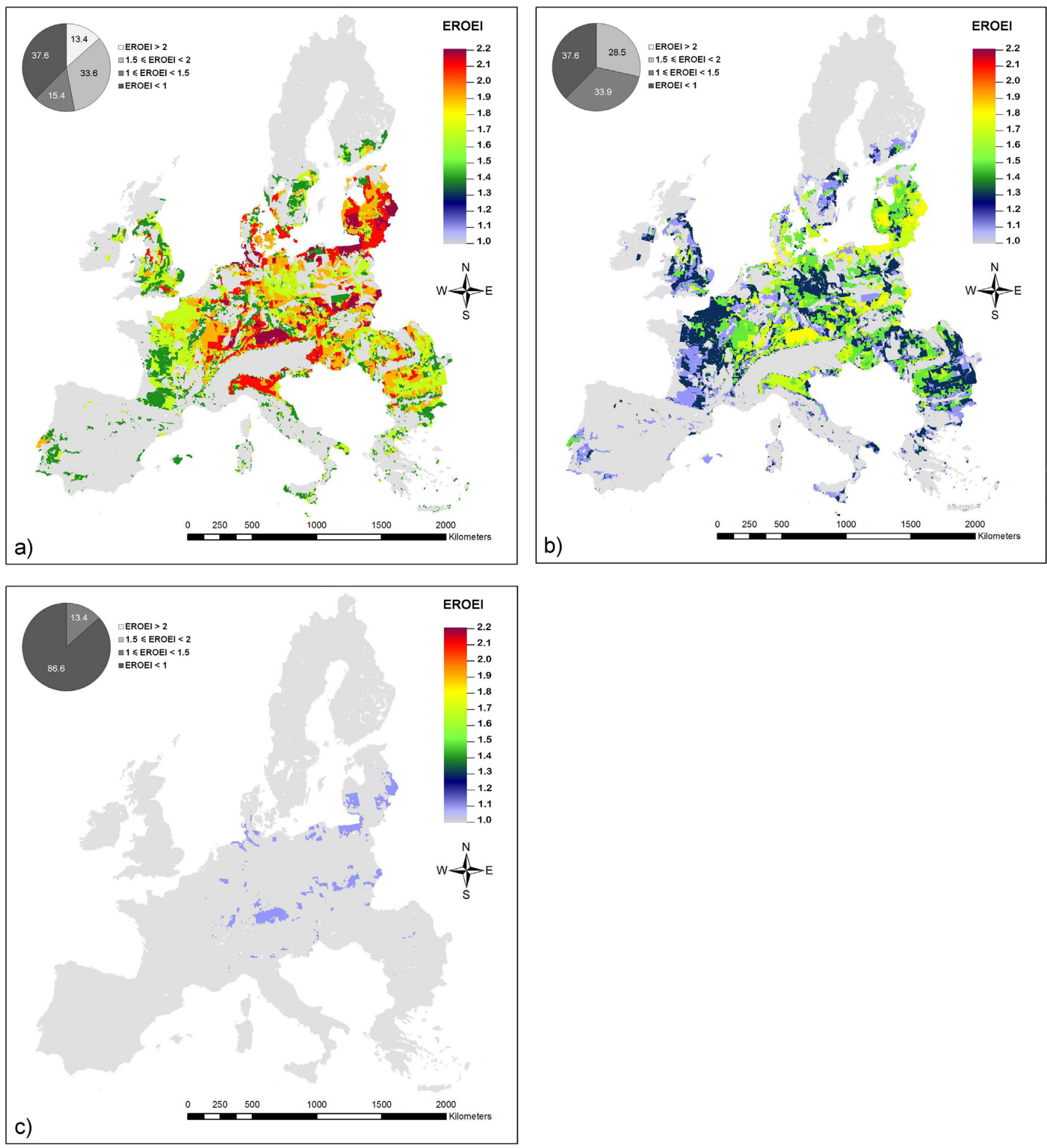

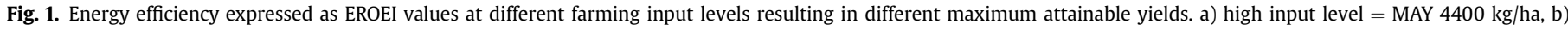
medium input level = MAY $2650 \mathrm{~kg} / \mathrm{ha}$ and c) low input level = MAY $1000 \mathrm{~kg} / \mathrm{ha}$.

\section{Discussion}

We have seen that the maximum EROEI (Energy Return On Energy Investment) value across Europe is found to be 2.2. Under the lowest MAY (maximum attainable yield) of 1000, energy efficiency is hardly above 1 , making low-input rapeseed farming infeasible in terms of energy efficiency. The higher MAYs of 2650 and $4400 \mathrm{~kg} / \mathrm{ha}$ do increase EROEI but not very substantially. EROEI values remain low: when yields are 4 times higher, EROEI only doubles. Higher MAYs are achieved by investing more in the rapeseed biofuel production process. More fertilizers, more effort in cultivation and more chemicals immediately translate into higher energy inputs. Roughly one third of Europe is unsuitable for rapeseed production; around one third of the area produces 


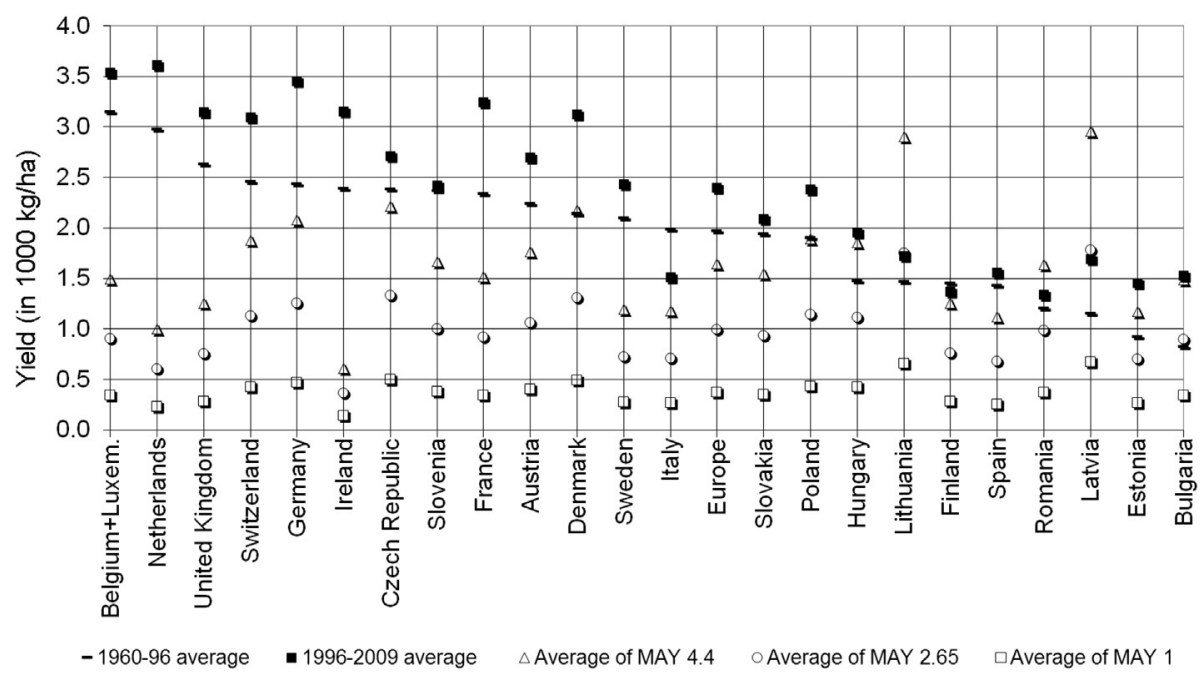

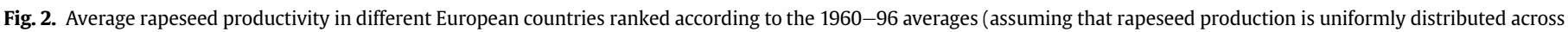
all suitability classes with no preference - scenario 1 ).

rapeseed biofuel with an energy loss and only around a third of the area in Europe falls in the top 4 suitability classes where at least no energy losses are expected from rapeseed biofuel production. These are average estimates and they can certainly be different for individual farms and locations. More detailed information about production techniques under different agro-climatic conditions could improve our estimates. But the general picture shows that efficiency of rapeseed biofuel production under existing agricultural practices and conversion technologies is too low to be a promising solution.

The EROEI distribution over Europe led to new interesting questions and hypotheses. Especially, considering the fact that many West European countries ended up on the left hand side of Figs. 2 and 4 while many East European countries are on the right hand side. Since we have no reason to assume that in the East production is deliberately confined to less suitable areas we can assume that West European countries simply have more intensive agriculture practices resulting in higher yields, while in many East
European countries agricultural practices are somewhat less efficient. This is because FAO reported yields for East European countries are even lower than what we would expect based on their averaged suitability indices with MAY $=4400 \mathrm{~kg} / \mathrm{ha}$ (in Lithuania, Latvia, Romania). At the same time, making these comparisons is not straightforward because we do not know where exactly in countries the yield has been produced.

Theoretically limiting production to the most suitable areas immediately increases the average yields. However we should keep in mind that those most suitable areas are likely to be most suitable also for other crops, potentially creating a conflict between crop growth for food vs. for fuel. The assumptions presented as scenarios 2 and 3 are certainly realistic because according to FAO so far the total area under rapeseed is less than the total area of the top 4 or top 3 suitability classes for all countries. And doing so, Europe can potentially produce rapeseed biofuel more efficiently. However this will come at a cost of using land for producing fuels instead of supplying food.

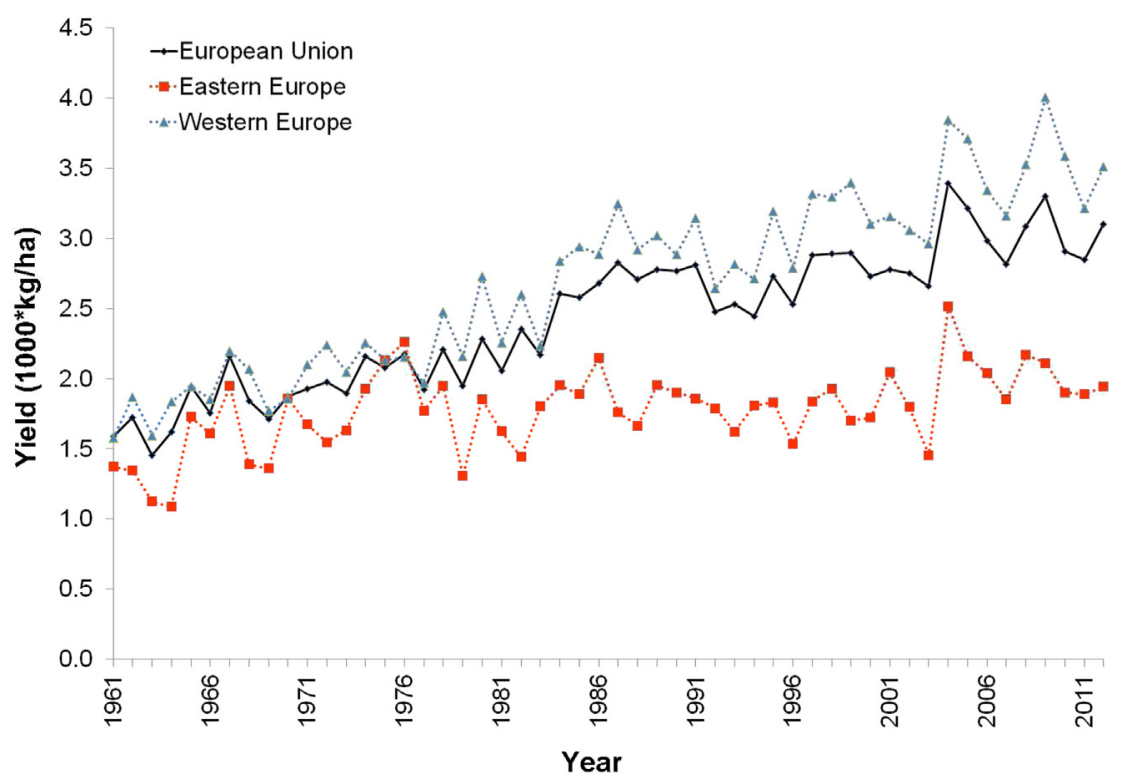

Fig. 3. FAO reported yield developments for rapeseed in Europe over the last fifty years [42]. 


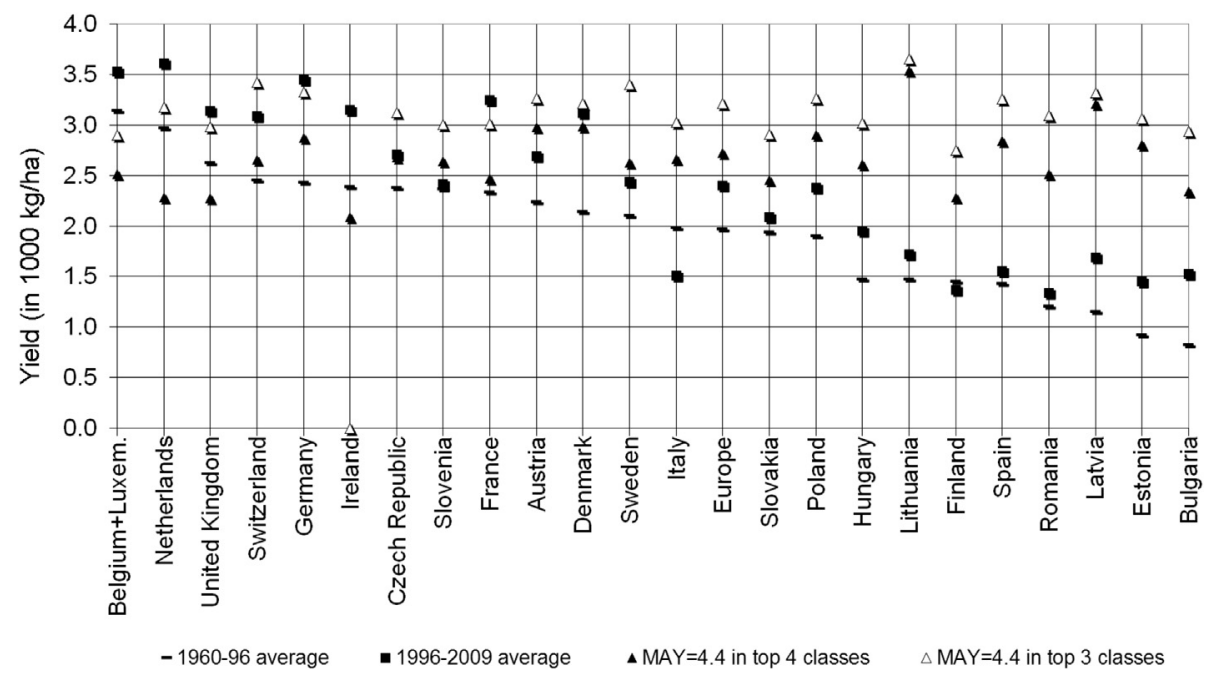

Fig. 4. Comparison of FAO reports with GAEZ estimates assuming production only in the top 3 and 4 most suitable classes - scenarios 2 and 3.

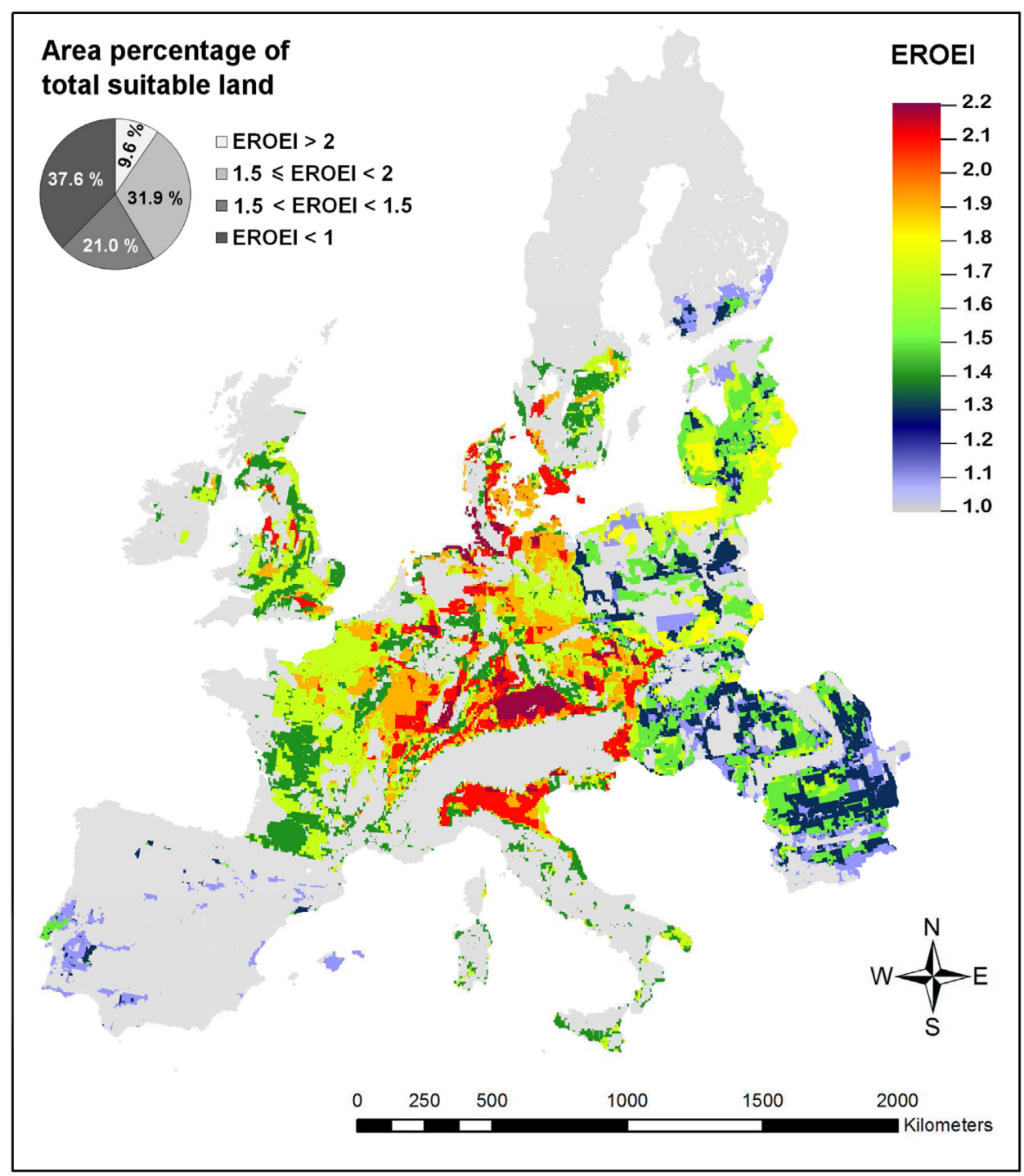

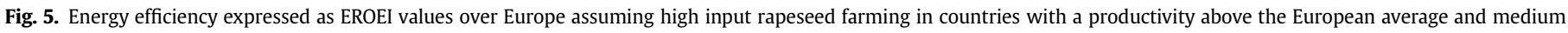
input rapeseed farming in countries with a productivity below the European average. 


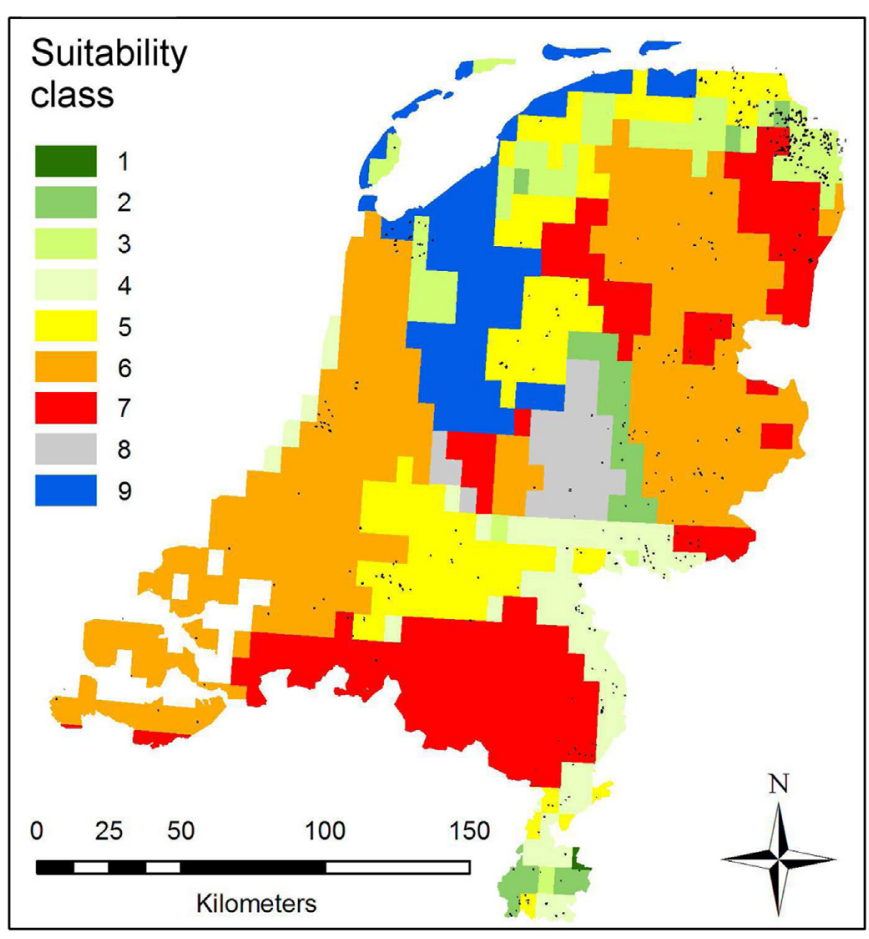

Fig. 6. Suitability classes in the Netherlands (based on GAEZ suitability maps [44]) and the areas where rapeseed was really produced in 2009 (based on Ministry of Agriculture data [43]).

Looking into the FAO data we may hypothesize that during last decades, MAY might have been increased due to use of more productive crop varieties. The high yield of 4.6 thousand $\mathrm{kg} / \mathrm{ha}$ for the Netherlands in 2009 may support this hypothesis. However, again we do not know if this MAY is sustainable or if yields were artificially pushed higher beyond the agricultural capacity, most likely at higher environmental costs. Likely, it is a bit of both. Combining information on crop varieties used by farmers linked with more detailed productivity results from test farms (linking different onfarm practices to yields of different varieties) are required to make a solid claim on this issue.
Looking into the Dutch rapeseed production areas we see that they are, as expected, mainly concentrated in the more suitable areas. It is only natural to allocate crop production first of all to areas that are best suited for that. The fact that Dutch rapeseed growers also appear to be present in areas where according to GAEZ classification they should not be present at all, may be an unsustainable situation. But it could also show that local conditions may be different from the generalized and spatially aggregated coarse suitability classification from GAEZ. Rapeseed production in the Netherlands showed in 2009 an exceptionally high productivity. This could be due to improvements in varieties used. It may also be an indication that yields are achieved in an unsustainable way by applying significant amounts of fertilizers to raise the yields beyond sustainable MAY even on marginally suitable lands, meaning that certain factors such as soil degradation, water pollution, etc. are not taken into account. It shows in any way that for full-cost accounting, we have to assume that only higher energy inputs can produce the high yields and compensate for the externalities.

Our results show that when energy efficiency is taken into account, the RME potential of Europe is significantly lower than what comes from the estimates based on biomass productivity only $[40,46]$. This only shows the importance of more comprehensive LCA studies in this area, taking into account all the technological developments as well as the restrictions that are driven by land availability, environmental quality and social acceptance.

\section{Conclusions}

There is still a lot of uncertainty in how energy efficiency can be estimated across large spatial domains with much heterogeneity both in agricultural, climatic and technological practices. In terms of energy efficiency, rapeseed production does not look very promising in Europe as a source of bioenergy. Even in most favorable conditions we are seeing EROEI of 2.2 and hardly any higher. There may be some local pockets where the growing conditions are especially favorable and where EROEI values are yet higher. However it always remains a problem whether we want to use these prime agricultural lands to produce energy or food. The low energy efficiency of rapeseed biodiesel production causes further concerns, especially in the long term, bearing in mind numerous externalities associated with intensive agricultural practices, the high demands on land, high pollution and soil degradation. European countries

Table 5

Distribution of actual and expected rapeseed production areas (in ha) in NL over lands with various suitability classes and expected yields under different input levels.

\begin{tabular}{|c|c|c|c|c|c|c|c|c|}
\hline \multirow[b]{2}{*}{ Class } & \multirow[b]{2}{*}{$\begin{array}{l}\text { Actual field } \\
\text { area in a class }\end{array}$} & \multirow[b]{2}{*}{$\begin{array}{l}\text { Total area } \\
\text { in a class }\end{array}$} & \multirow[b]{2}{*}{$\begin{array}{l}\% \text { Area in } \\
\text { a class }\end{array}$} & \multirow[b]{2}{*}{$\begin{array}{l}\text { Expected field } \\
\text { area if uniformly } \\
\text { distributed }\end{array}$} & \multirow[b]{2}{*}{$\begin{array}{l}\text { Actual - } \\
\text { expected area }\end{array}$} & \multicolumn{3}{|c|}{ Total yield in $\mathrm{kg} / \mathrm{ha}$ for $\mathrm{MAY}=$} \\
\hline & & & & & & 4400 & 2650 & 1000 \\
\hline 1 & 0 & 15 & 0.05 & 1 & -1 & 0 & 0 & 0 \\
\hline 2 & 143 & 1145 & 3.65 & 82 & 61 & 583 & 351 & 133 \\
\hline 3 & 1017 & 2351 & 7.49 & 168 & 848 & 3467 & 2088 & 788 \\
\hline 4 & 210 & 2523 & 8.04 & 181 & 30 & 579 & 348 & 131 \\
\hline 5 & 384 & 5082 & 16.20 & 364 & 20 & 803 & 483 & 182 \\
\hline 6 & 331 & 12908 & 41.15 & 924 & -594 & 473 & 285 & 108 \\
\hline 7 & 161 & 7344 & 23.41 & 526 & -365 & 106 & 64 & 24 \\
\hline Total & 2246 & 31368 & 100.00 & 2246 & 0 & 6011 & 3621 & 1368 \\
\hline
\end{tabular}

Table 6

Dutch rapeseed yields in $1000 \mathrm{~kg} / \mathrm{ha}$ over the period 1999-2009.

\begin{tabular}{|c|c|c|c|c|c|c|c|c|c|c|c|}
\hline 1999 & 2000 & 2001 & 2002 & 2003 & 2004 & 2005 & 2006 & 2007 & 2008 & 2009 & Average \\
\hline 3.4 & 3.6 & 3.4 & 3.0 & 3.5 & 4.6 & 3.7 & 3.4 & 3.5 & 3.8 & 4.6 & 3.7 \\
\hline
\end{tabular}


may need to put more consideration to energy efficiency as one of the sustainability criteria for renewable energy production when considering their energy policies.

There is probably still potential for increasing rapeseed productivity in the majority of European countries. As we have seen it has already increased quite substantially during the past decade. Better varieties, improved agricultural technology and more efficient energy use can probably further increase the energy efficiency of bioenergy production from rapeseed. EROEI values vary spatially and consideration should always be given to where and why produce rapeseed. However in most cases it is still unlikely that the gains will be substantial enough to make rapeseed a sustainable source of bioenergy in the long term. Growing rapeseed remains to be quite an energy intensive operation and requires substantial inputs of energy at all stages of the production. Keeping agriculture mostly focused on food production and using agricultural waste to produce energy delivers much higher EROEI values [32] and should be given higher priority. Alternatively, as always, finding ways to curb energy demand instead of increasing supply by all means seems to be the most promising strategy [47].

\section{Acknowledgments}

We would like to thank the Gegevensmanagement Dienst Regelingen Assen from LNV for their permission to use their GIS layers with spatial distribution of rapeseed fields in the years 2000-2010. This study was enabled by Erasmus Mundus Scholarships for M. Firrisa and O. Arodudu. A. Voinov was partially supported by the BE2.0 (Bioenergy for Overijssel) project and by the EU-FP7-308601 COMPLEX project.

\section{References}

[1] Cleveland CJ, Costanza R, Hall CAS, Kaufmann R. Energy and the U.S. economy: a biophysical perspective. Science 1984;225(4665):890-7.

[2] IPCC. The physical science basis. In: Solomon S, Qin D, Manning M, Chen Z Marquis $\mathrm{M}$, et al, editors. Contribution of working group I to the fourth assessment report of the intergovernmental panel on climate change. Cambridge, United Kingdom and New York, NY, USA: Cambridge University Press; 2007. p. 996.

[3] Rockwell K. Alternative energy - why do we need it? [Internet]. U S: Ezinearticles; 2007 Oct 25 [cited 2011 Jan 26] Available from:, http:// ezinearticles.com/?Alternative-Energy--Why-do-we-Need-it? \&id=801280.

[4] Meinshausen M, Meinshausen N, Hare W, Raper SCB, Frieler K, Knutti R, et al. Greenhouse-gas emission targets for limiting global warming to 2 degrees C. Nature 2009;458(7242):1158-62.

[5] van der Hilst F, Dornburg V, Sanders JPM, Elbersen B, Graves A Turkenburg WC. Potential, spatial distribution and economic performance of regional biomass chains: the north of the Netherlands as example. Agric Syst 2010;103(7):403-17.

[6] Arvidsson R, Persson S, Froling M, Svanstrom M. Life cycle assessment of hydrotreated vegetable oil from rape, oil palm and Jatropha. J Clean Prod $2011 ; 19(2-3): 129-37$

[7] Baka J, Roland-Holst D. Food or fuel? what European farmers can contribute to Europe's transport energy requirements and the doha Round. Energy Policy 2009;37(7):2505-13.

[8] Batchelor SE, Booth EJ, Walker KC. Energy analysis of rape methyl ester (RME) production from winter oilseed rape. Industrial Crops Prod 1995;4(3): 193-202.

[9] Bomb C, McCormick K, Deurwaarder E, Kåberger T. Biofuels for transport in Europe: lessons from Germany and the UK. Energy Policy 2007;35:2256.

[10] Cherubini F, Birda ND, Cowie A, Jungmeiera G, Schlamadinger B, WoessGallascha S. Energy and greenhouse gas LCA of biofuel and bioenergy systems: key issues, ranges and recommendations. Resour Conservation Recycl 2009;53(8):434-47.

[11] Network EurActiv. Biofuels: the next generation [Internet]. Brussels (Belgium): EurActiv Network; 2007 Sep 18 [updated 2009 Jul 13, cited 2013, Jul 10]. Available from:, http://www.euractiv.com/energy/biofuelsgeneration-linksdossier-188433.

[12] European Biodiesel Board. What is biodiesel? [Internet]. Brussels (Belgium): European Biodiesel Board; c2003-2013 [updated 2013 Jul 11, cited 2013, Jul 18]. Available from: http://www.ebb-eu.org/biodiesel.php.

[13] McAlister S, Horne RE. Climate change responses: carbon offsets, biofuels and the life cycle assessment contribution. In: Horne RE, Grant T, Verghese KL, editors. Life cycle assessment: principles, practice and prospects. Australia: CSIRO Publishing: 2009.

[14] Nanaki EA, Koroneos CJ. Comparative LCA of the use of biodiesel, diesel and gasoline for transportation [CD-ROM]. In: Proceedings of the 1st international exergy, life cycle assessment, and sustainability workshop \& symposium (ELCAS-1); 2009 Jun 4-6. p. 464-71. Nisyros, Greece.

[15] Davis SC, Anderson-Teixeira KJ, DeLucia EH. Life-cycle analysis and the ecology of biofuels. Trends Plant Sci 2009;14(3):140-6.

[16] Ajanovic A. Biofuels versus food production: does biofuels production increase food prices? Energy 2010;36(4):2070-6.

[17] Demirbas A. Biofuels sources, biofuel policy, biofuel economy and globa biofuel projections. Energy Convers Manag 2008;49(8):2106-16.

[18] Cherubini F, Strømman AH. Life cycle assessment of bioenergy systems: state of the art and future challenges. Bioresour Technol 2010;102(2): 437-51.

[19] Halleux H, Lassaux S, Renzoni R, Germain A. Comparative life cycle assessment of two biofuels ethanol from sugar beet and rapeseed methyl ester. Int J Life Cycle Assess 2008;13(3):184-90.

[20] Hammond GP, Kallu S, McManus MC. Development of biofuels for the UK automotive market. Appl Energy 2008;85(6):506-15.

[21] Kavalov B. Biofuel potentials in the EU. Seville (Spain): The European Commission: Institute for Prospective Technological Studies and European Commission Joint Research Centre; 2004. p. 35.

[22] Crutzen PJ, Mosier AR, Smith KA, Winiwarter W. $\mathrm{N}_{2} \mathrm{O}$ release from agrobiofuel production negates global warming reduction by replacing fossi fuels. Atmospheric Chem Phys 2008;8(2):389-95.

[23] PBL. Serious indirect effects of some biofuels on global biodiversity and greenhouse gas emissions [Internet]. Den Haag (Netherlands): Netherlands Environmental Assessment Agency (PBL); 2010 [cited 2010 Nov 10]. Available from:, http://www.pbl.nl/en/news/pressreleases/2010/20100531-Seriousindirect-effects-of-some-biofuels-on-global-biodiversity-and-greenhousegas-emissions.html.

[24] Smith L. Rapeseed biofuel 'produces more greenhouse gas than oil or petrol. London (United Kingdom): Times Newspapers Ltd; 2007 Sep 22.

[25] VROM. Biofuels [Internet]. Den Haag (Netherlands): Ministry of Infrastructure and the Environment; 2010 [cited 2010 Aug 25]. Available from:, http:// international.vrom.nl/pagina.html?id=37483.

[26] Bureau JC, Disdier AC, Gauroy C, Tréguer D. A quantitative assessment of the determinants of the net energy value of biofuels. Energy Policy 2009;38(5): 2282-90.

[27] Purdue University. Brassica napus L [Internet]. Pittsburgh (USA): Purdue University [cited 2010 Nov 4]. Available from: http://www.hort.purdue.edu/ newcrop/duke_energy/Brassica_napus.html.

[28] Thamsiriroj T, Murphy DJ. Can rape seed biodiesel meet the european union sustainability criteria for biofuels? Energy Fuels 2010;24(2): $1720-30$.

[29] Murphy DJ, Hall CAS, Powers B. New perspectives on the energy return on (energy) investment (EROI) of corn ethanol. Environ Dev Sustain 2011;13(1): 179-202.

[30] Firrisa MT, van Duren I, Voinov AA. Energy efficiency for rapeseed biodiese production in different farming systems. Energy Effic 2013;7:79-95.

[31] Börjesson P. Good or bad bioethanol from a greenhouse gas perspective what determines this? Appl Energy 2008;86(5):589-94.

[32] Arodudu O, Voinov A, van Duren I. Assessing bioenergy potential in rural areas - a NEG-EROEI approach. Biomass Bioenergy 2013;58:350-64.

[33] Cleveland CJ. Energy return on investment (EROI) [Internet]. Washington, D.C. (USA): environmental information coalition, National council for science and the environment. In: Constanza R, editor. Encyclopedia of earth; 2006 Sep 18 [rev. 2008 Apr 16; cited 2010 Nov 4]. Available from: http://www.eoearth.org/ article/Energy_return_on_investment_(EROIhttp://www.eoearth.org/article/ Energy_return_on_investment_(EROI).

[34] Hall CAS, Balogh S, Murphy DJ. What is the minimum EROI that a sustainable society must have? Energies 2009;2(1):25-47.

[35] Mulder K, Hagens NJ. Energy return on investment: toward a consistent framework. Ambio 2008:37(2):74-9.

[36] Hall CAS, Murphy DJ, Gagnon N. Order from chaos (hopefully): a preliminary protocol for determining EROI for fuels. In: Proceedings of ASPO-USA conference. Boston, USA; 2006 Oct 25-27.

[37] Murphy DJ, Hall CAS. Year in review-EROI or energy return on (energy) invested. Ann N Y Acad Sci 2010;1185(2):102-18.

[38] The Offshore Valuation Group. The offshore valuation: a valuation of the UK's offshore renewable energy resource. Powys (Wales, United kingdom): The Offshore Valuation Group, Public Interest Research Centre (PRIC); 2010.

[39] Fiorese Guariso G. A GIS-based approach to evaluate biomass potential from energy crops at regional scale. Environ Model Softw 2010;25(6): $702-11$.

[40] Fischer G, Prieler S, van Velthuizen H, Lensink SM, Londo M, de Wit M. Biofuel production potentials in Europe: sustainable use of cultivated land and pastures. Part I: land productivity potentials. Biomass Bioenergy 2010;34(2): $159-72$.

[41] De Vries SC, van de Ven GWJ, van Ittersum MK, Giller KE. Resource use efficiency and environmental performance of nine major biofuel crops, processed by first-generation conversion techniques. Biomass Bioenergy 2010;34(5): 588-601. 
[42] FAOSTAT. Food and agricultural commodities [Internet]. Rome (Italy): Food and Agriculture Organization of the United Nations (FAO); 2010 [cited 2010 Nov 4]. Available from:, http://faostat.fao.org/site/567/default.aspx\#ancor.

[43] LNV. Spatial distribution of rapeseed production in the Netherlands. Den Haag (Netherlands): Gegevensmanagement Dienst Regelingen Assen (Ministry of Agriculture); 2010.

[44] GAEZ. Global suitability map for rainfed rapeseed [Internet]. Laxenburg (Austria): International Institute for Applied Systems Analysis (IIASA) and Food and Agriculture Organization of the United Nations (FAO); 2010 [cited 2010 Nov 4]. Available from:, http://www.gaez.iiasa.ac.at/.
[45] European Soil Portal. Shape files of country maps [Internet]. Ispra (Italy): Institute for Environment and Sustainability (IES), European Commission Joint Research Centre; 2010 [cited 2010 Nov 4]. Available from:, http://eusoils.jrc. ec.europa.eu/.

[46] Hellmann F, Verburg PH. Spatially explicit modelling of biofuel crops in Europe. Biomass Bioenergy 2011;35(6):2411-24.

[47] Voinov A, Filatova T. Pricing strategies in inelastic energy markets: can we use less if we can't extract more? Front Earth Sci 2014;8(1):3-17. 